\title{
Learning Style Preferences of EFL College Students and Their Causes
}

\author{
Wei-Huan Chang1, Hui-Jing Hsiao², I-Ju Chen ${ }^{2 *}$ \\ ${ }^{1}$ General Education Center, Ling Tung University, Taiwan \\ ${ }^{2}$ Department of Applied Foreign Languages, Ling Tung University, Taiwan \\ Email: jocelyn.chang@teamail.ltu.edu,p10501@teamail.ltu.edu.tw, *p10127@teamail.ltu.edu.tw
}

How to cite this paper: Chang, W.-H., Hsiao, H.-J., \& Chen, I.-J. (2019). Learning Style Preferences of EFL College Students and Their Causes. Open Journal of Modern Linguistics, 9, 59-66. https://doi.org/10.4236/ojml.2019.92006

Received: January 28, 2019

Accepted: April 1, 2019

Published: April 4, 2019

Copyright () 2019 by author(s) and Scientific Research Publishing Inc. This work is licensed under the Creative Commons Attribution International License (CC BY 4.0).

http://creativecommons.org/licenses/by/4.0/

\begin{abstract}
This study investigated the learning styles of two students of English as a Foreign Language (EFL) at the college level in Taiwan. Using a learning style preference checklist and semi-structured interview, their perceptional learning styles were first explored in terms of preferences and the underlying reasons for these preferences. Two participants with different majors participated in the present study. The results indicated that the learner majoring in a business-related field preferred the auditory style of learning, whereas the learner with a design background favored the haptic style. Learning background may play a vital role in the development of a learner's learning style. Learning preferences may also relate to a student's learning experience and peer learning performance. Style preferences in the EFL learning environment may change over time, across contexts, and between different tasks.
\end{abstract}

\section{Keywords}

Learning Styles, EFL Learners, Auditory Style, Haptic Style

\section{Introduction}

As awareness of individual differences throughout the learning process has increased, a learner's learning style has been recognized as a potential factor affecting that learner's performance (Sadeghi et al., 2012; Blaire, 1982, as cited in Gohar \& Sadeghi, 2015). The claim that learning style could be a personal factor contributing to learning outcomes and could be influential in English education (Chen, 1999) has been widely discussed in the past few decades.

Researchers have defined learning style from general conceptions to more complicated identifications (Alkooheji \& Al-Hattami, 2018; Awang, Samad, Mohd Faiz, Roddin, \& Kankia, 2017; Cimermanova, 2018; Gohar \& Sadeghi, 
2015; Uhrig, 2015; Zhang, Quan, Huang, \& Kuo, 2017). Some scholars have described learning style as the preferences a learner exhibits in the learning process (Lee, 2011), such as the use of certain methods or strategies (Lui, 2012), cognitive and interactional patterns (Scarcella, 1990, as cited in Lui, Hu, \& Gan, 2013), and the particular ways in which a learner processes information (Bicer, 2014; Awang, Samad, Mohd Faiz, Roddin, \& Kankia, 2017; Zhang, Quan, Huang, \& Kuo, 2017). Other researchers have referred to learning style as the characteristic means by which learners acquire, retain, and retrieve information (Alkooheji \& Al-Hattami, 2018; Soureshjani \& Naseri, 2012; Bailey, Onwuegbuzie, \& Daley, 2000), stable indicators of cognitive, affective, and physiological characteristics (Lui, Hu, \& Gan, 2013; Gohar \& Sadeghi, 2015), and the way learners concentrate on, and internalize, and retain new information (Cutolo \& Rochford, 2007). Learning style has also been considered a model that is based on the learner's sensory inputs, absorption of knowledge, and approach to learning (Cimermanova, 2018).

Alluding to studies in which learning style was concluded to be consistent during an individual's information processing (Naserieh \& Sarab, 2013) and intrinsic to the learner and dependent on the learning task context (Dornyei, 2005), Uhrig (2015) posited that an individual's specific preferences in the learning process appear to shift along a particular continuum as they are required to process different information. Research has resulted in different categories, theories, criteria, and aspects of learning styles being proposed (Cimermanova, 2018), which in turn has resulted in various methods of assessing learning style, such as the Learning Style Model of Kolb (1984), Perceptual Learning Style Preference Questionnaire (PLSPQ) of Reid (1984), Learning Channel Preference Checklist (LCPC) of O'Brien (1990), Productivity Environmental Preference Survey (PEPS) of Dunn et al. (1991), VARK (Visual, Aural, Read/Write, Kinesthetic) Learning Style of Flemming (1995), and Building Excellence (BE) of Ruddle and Dunn (2000).

Among these various instruments, Kolb's Learning Style Model places more emphasis on experiential learning theory, whereas Flemming's VARK Learning Style is the sensory model. These two instruments have four sentences per item. However, Kolb's model contains only 12 items, while Flemming's model comprises 16 items (Alkooheji \& Al-Hattami, 2018; Gohar \& Sadeghi, 2015). As researchers have indicated, the reliability of the PEPS subscales ranged from 0.44 to 0.87 , whereas the reliability of BE ranged from .68 to .87 . Naserieh and Sarab (2013) criticized the validation of the PLSPQ questionnaire, finding inconsistent reliability indexes among its subscales. Instruments for assessing learning style appear to have problems with their reliability or validity when applied across different cultures (Bailey et al., 2000; Cutolo \& Rochford, 2007). Therefore, researchers have called for more studies to be conducted from different perspectives (Gohar \& Sadeghi, 2015; Bicer, 2014; Soureshjani \& Naseri, 2012) and have indicated the need to determine learners' learning styles in specific contexts 
(Uhrig, 2015).

Most research on learning style has employed survey instruments to examine the relationships between style preferences and different variables, such as achievements, learning strategies, gender, and age (Awang et al., 2017; Cimermanova, 2018; Kim \& Kim, 2014; Liu et al., 2013; Naserieh \& Sarab, 2013; Uhrig, 2015; Zhang et al., 2017). Few studies have investigated why individual learners prefer different styles. Therefore, this exploratory study used two cases to examine differences in learning style at the college level in Taiwan. The objective was to obtain rich data regarding college students' learning style preferences and identify factors that may affect the ways in which students learn. To fulfil this objective, the following questions had to be addressed. First, whether preferred learning style is affected by a learner's major, and second, what factors affect learning style preferences in terms of different learning tasks.

\section{Methodology}

\subsection{Participants}

Two EFL students with different educational backgrounds participated with the aim of discovering whether learning style was affected by a student's major. Both participants were senior students from the same college. Jean was majoring in Finance and was on the Business Program, whereas Ray was majoring in Visual Communication and was on the Design Program at the college level. Both had been learning English for more than nine years and had already taken four credits worth of English courses in their college. The participants had an intermediate level of English achievement, earning B grades.

\subsection{Instruments}

The Chinese version (Chen, 1999) of the LCPC of O'Brien (1990) was used to determine the participants' major perceptional language learning style preferences. According to Chen (1999), the LCPC is sensitive to different styles caused by cultural differences and is a useful style inventory with high reliability (Oxford, 1992; Kroonenberg, 1995; Oxford, 1995, as cited in Chen, 1999). Comprising 36 statements, the LCPC is self-scoring and has three perceptual categories of learning style preference: visual, auditory, and haptic (kinesthetic and tactile). The LCPC is scored using a 5-point Likert scale ranging from "almost never" (1) to "almost always" (5). The number indicates how often the respondent uses certain styles. To avoid interference caused by the learners' English language abilities, Chen's Chinese-version LCPC was employed, which has a test-retest reliability of 0.86 and has obtained face validity by being checked by five experts in the field of English teaching.

In addition to the questionnaire, a semi-structured interview was conducted to construct a fuller description of specific styles, enable learners to fully form their own opinions, and obtain more focused and complete information. Each interview lasted approximately 20 minutes. The interview questions, which were 
based upon the questionnaire responses, focused on participants' specific uses of certain learning styles.

\subsection{Procedures}

The researchers first employed the Normed Learning Style Survey to explore the participants' learning styles. To completely understand the participants' patterns of learning styles, the semistructured interview was conducted in the participants' native language to avoid misunderstanding caused by nonnative language use. The interviews were recorded, transcribed, and analyzed in terms of the learners' preferences in different learning contexts.

\subsection{Data Analysis}

The data were first analyzed and identified by calculating the total scores for all three categories. The sum of items $1,5,9,10,11,16,17,22,26,27,32$, and 36 is the visual preference score, whereas the sum of items $2,3,12,13,15,19,20,23$, $24,28,29$, and 33 is the auditory preference score. The sum of the other items is the haptic preference score. Style preference was transformed into percentages, and the highest percentage indicated a participant's major learning style. After this preliminary analysis, the interview data in different learning contexts were compared.

\section{Results and Discussion}

\subsection{Jean}

Jean's learning style checklist revealed that Jean preferred auditory learning (37\%), followed by visual (34\%) and haptic (29\%) learning. Among the 36 statements, "I remember something better if I write it down" (item 1), "When reading, I listen to the words in my head or I read aloud" (item 2), and "I need frequent breaks when I study" (item 7) were the strategies almost always used by Jean. Among the 12 statements in the auditory category, Jean often used the following seven styles: those corresponding to items 2, 12, 19, 23, 24, 28, and 29.

After this analysis of the survey data, an in-depth interview was conducted to elicit the possible reasons for Jean's preferences. As an auditory learner, Jean reported, "I always listen to the words in my head or read aloud when reading (item 2) because my English teacher always asked us to repeat after her and told us we will understand the article if we read it aloud". This statement implies that a teacher's instructional style plays a crucial role in the development of students' learning styles. Furthermore, Jean mentioned, "I often prefer having someone tell me how to do something rather than having to read the directions myself (item 12) because the experience from others is the best teacher. I would rather listen to others' suggestions than complete tasks by myself". This viewpoint echoed the findings of previous researchers that females seem to focus on the speaker with greater interest, empathy, concern, and politeness than do males (Lakoff, 1975; Kramarae, 1981, and Tannen 1986, 1990, as cited in Reid, 1995). 
As Oxford (1995) reported, "field-sensitive individuals, often females, with their more interpersonal interaction might do better in overall communication competence" (as cited in Reid, 1995). In addition, Jean made the following statements:

I often remember what people say better than what they look like (item 19). In fact, I am a talented listener. Most of my teachers like to write on the board and ask us to take notes. However, I think I am a slow note-taker. I always record teachers' lectures and review what I have learned by using my MP3.

Jean's teacher appears to have preferred visual learning because the teacher wrote important information on the chalkboard and encouraged students to take notes. However, Jean tended to be an auditory learner. This is a learning style mismatch, and mismatched students "did report suffering from the mismatch... This situation would somehow make their learning less efficient and fruitful" (Chen, 1999: p. 88).

\subsection{Ray}

The questionnaire data indicated that Ray was a haptic learner. Ray had a relatively high tendency to employ auditory and visual learning strategies. His haptic percentage in the checklist was $37 \%$; auditory, $32 \%$; and visual, $31 \%$. Among the 36 statements, item 24 and three items from the haptic category were the strategies always used by Ray. Among the 12 statements in the haptic category, Ray almost always used the strategies indicated in items 6,7 , and 35 and often utilized those indicated in items 21 and 34. These findings correspond to Oxford's claim that "some auditory style preferences have been shown more by females than by males, and tactile or kinesthetic style preferences relate more closely to males than to females" (as cited in Reid, 1995: p. 40). Learning style may be related to the gender variable to some extent (Naserieh \& Sarab, 2013; Bicer, 2014; Cutolo \& Rochford, 2007; Alkooheji \& Al-Hattami, 2018).

As a haptic learner, Ray reported high frequency of the use of three haptic styles. Firstly, he stated the following:

I always study better when music is playing [item 6] because my mind is relaxed when I listen to pop music. I am a furniture designer, and music is essential to inspire the creation of art. Actually, most of my classmates do the same thing, and so does my teacher. I think it has become my study habit.

The statement may reflect the concept proposed by Bassano and Christison (1995), who indicated that "artwork, always emotionally charged, arises from and stimulates feelings, and it can be used within any curriculum" (as cited in Reid, 1995: p. 66). In this context, music appears to play an affective role in facilitating language learning, especially for learners in artistic fields. In addition, Ray pointed out, "I need frequent breaks when studying (item 7) because breaks 
are the best time for recalling what I have learned and I can absorb more after the break. I usually have a 10-minute break after 30 minutes of study". As a male learner, Ray required some movement while learning; therefore, he needed more frequent breaks than the female learner, Jean, who needed 10-minute breaks for every 2 hours of study. This reflects Oxford's claim that "kinesthetic students require movement and frequent breaks in activity. These are the students who cannot sit still for longer than 20 minutes at a time" (as cited in Reid, 1995: p. 36). Furthermore, Ray mentioned, "I prefer to complete a project rather than write a report (item 35). A project is more concrete than a report. In fact, my teacher said that completing a project is more valuable than writing a report". This result is in agreement with the assertion that male learners who have a tactile preference "need to touch and handle objects. They are happy making collages, three-dimensional models, shadow-boxes, or other artwork" (as cited in Reid, 1995: p.35). In addition to the gender difference in learning style preference, teachers' beliefs and instructional styles also appear to influence learners' learning style.

\section{Conclusion}

In this investigation of the differences in perceptional learning styles between two students, Jean and Ray, Jean was discovered to be an auditory learner, whereas Ray was a haptic learner. In this case, gender differences may have existed between the two learners' sensory preferences. However, after generating depth of personal perception by conducting interviews, the authors found that style differences may have been related to gender, the teaching beliefs and styles of the students' teachers, the students' learning experience, and their peer learning experience. This study thus reveals that learning preference is not an innate habit but may vary in accordance with teachers' instructional styles. Learning preferences may also relate to learners' learning experiences or peer learning performance. Style preference in the English as a Foreign Language learning environment may change across contexts, between different tasks, and over time.

\section{Conflicts of Interest}

The authors declare no conflicts of interest regarding the publication of this paper.

\section{References}

Alkooheji, L., \& Al-Hattami, A. (2018). Learning Style Preferences among College Students. International Education Studies, 11, 50-63. https://doi.org/10.5539/ies.v11n10p50

Awang, H., Samad, N. A., Mohd Faiz, N. Z., Roddin, R., \& Kankia, J. D. (2017). Relationship between Learning Styles Preferences and Academic Achievement. International Research and Innovation Summit, 226, 1-5.

Bailey, P., Onwuegbuzie, A. J., \& Daley, C. E. (2000). Using Learning Style to Predict Foreign Language Achievement at the College Level. System, 28, 115-133. 
https://doi.org/10.1016/S0346-251X(99)00064-0

Bassano, S., \& Christison, M. A. (1995). Drawing Out Communication: Student-Created Visuals as a Means for Promoting Language Development in Adult ESL Classrooms. In J. M. Reid (Eds.), Learning Styles in ESL/EFL Classroom (pp. 34-46). Boston: Heinle \& Heinle Publishers.

Bicer, D. (2014). The Effect of Students' and Instructors' Learning Styles on Achievement of Foreign Language Preparatory School Students. Procedia-Social and Behavioral Sciences, 141, 382-386. https://doi.org/10.1016/j.sbspro.2014.05.067

Chen, Y. C. (1999). The Perceptual Learning Style Preferences of Taiwanese Junior High School Students in Learning English. Unpublished Master Thesis, Changhua: National Changhua University of Education.

Cimermanova, I. (2018). The Effect of Learning Styles on Academic Achievement in Different Forms of Teaching. International Journal of Instruction, 11, 219-232. https://doi.org/10.12973/iji.2018.11316a

Cutolo, A., \& Rochford, R. A. (2007). An Analysis of Freshmen Learning Styles and Their Relationship to Academic Achievement. College Quarterly, 10, 1-17.

Dornyei, Z. (2005). The Psychology of the Language Learner: Individual Differences in Second Language Acquisition. Mahwah, NJ: Erlbaum.

Dunn, R., Dunn, K., \& Price, G. E. (1991). Productivity Environmental Preference Survey. Lawrence, KS: Price Systems, Inc.

Flemming, N. D. (1995). I'm Different; Not Dumb. Modes of Presentation (VARK) in the Tertiary Classroom. In A. Zelmer, (Ed.), Research and Development in Higher Education. Proceedings of the 1995 Annual Conference of the Higher Education and Research Development Society of Australia (HERDSA) (pp. 308-313).

Gohar, M. J., \& Sadeghi, N. (2015). The Impact of Learning Style of Preferences on Foreign Language Achievement: A Case Study of Iranian EFL Students. Procedia-Social and Behavioral Sciences, 171, 754-764. https://doi.org/10.1016/j.sbspro.2015.01.188

Kim, T. Y., \& Kim, Y. K. (2014). A Structural Model for Perceptual Learning Styles, the Ideal L2 Self, Motivated Behavior, and English Proficiency. System, 46, 14-27. https://doi.org/10.1016/j.system.2014.07.007

Kolb, D. A. (1984). Experiential Learning: Experience as the Source of Learning and Development. Englewood Cliff, NJ: Prentice-Hall.

Lee, Y. J. (2011). English Learning Styles of Students from East Asian Countries: A Focus on Reading Strategies. International Education Studies, 4, 75-81. https://doi.org/10.5539/ies.v4n2p75

Liu, F., Hu, L., \& Gan, J.J. (2013). A study on the Learning Style Preferences with Different Academic Backgrounds-Taking Tujia EFL Learners As examples. Theory and Practice in Language Studies, 3, 100-107. https://doi.org/10.4304/tpls.3.1.100-107

Lui, F. (2012). A Probe into the EFL Learning Style Preferences of Minority College Students: A Empirical Study of Tujia EFL Learners in Jishou University. Theory and Practice in Language Studies, 8, 172-177.

Naserieh, F., \& Sarab, M. R. A. (2013). Perceptual Learning Style Preferences among Iranian Graduate Students. System, 41, 122-133. https://doi.org/10.1016/j.system.2013.01.018

O’Brien, L. (1990). Learning Channel Preference Checklist (LCPC). Rockville, MD: Specific Diagnostic Services.

Oxford, R. L. (1995). Gender Differences in Language Learning Styles: What Do They Mean? In J. M. Reid (Eds.), Learning Styles in ESL/EFL Classroom (pp. 34-46). Boston: 
Heinle \& Heinle Publishers.

Reid, J. M. (1984). Perceptual Learning Style Preference Questionnaire. Laramie: University of Wyoming, Department of English.

Reid, J. M. (1995). Learning Styles in ESL/EFL Classroom (pp. 34-46.). Boston: Heinle \& Heinle Publishers.

Ruddle, S., \& Dunn, R. (2000). Building Excellence. Pittsford, NY: Performance Concepts International.

Soureshjani, K. H., \& Naseri, N. (2012). Perceptual Learning-Style Preferences of Iranian EFL Learners in Relation to Their Proficiency Level. American Journal of Linguistics, 1, 70-74. https://doi.org/10.5923/j.linguistics.20120104.01

Uhrig, K. (2015). Learning Styles and Strategies for Language Use in the Context of Academic Reading Tasks. System, 50, 21-31. https://doi.org/10.1016/j.system.2015.02.002

Zhang, M., Quan, Y., Huang, L., \& Kuo, Y. L. (2017). The Impact of Learning Styles on Academic Achievement. International Journal of Intelligent Technologies and Applied Statistics, 10, 173-185. 